Maan Alkhateeb,

Ph.D., Palestine Technical University, Palestine

(iD) ORCID ID 0000-0002-1626-2916

email: m.khateeb@ptuk.edu.ps

Rania Abdalla,

Palestine Technical University, Palestine

iD ORCID ID 0000-0002-1626-2916

email: $\underline{\text { m.khateeb@ptuk.edu.ps }}$

Correspondence author: m.khateeb@ptuk.edu.ps

\title{
INNOVATIONS IN HUMAN RESOURCES MANAGEMENT: IMPACT OF SOCIAL MEDIA USE ON EMPLOYEES' PERFORMANCE
}

Abstract. Social media has changed the modes of all aspects of business operations, particularly human resource management practices. Firms are increasingly using social media tools to facilitate information sharing among their employees in an attempt to improve the innovation process and firm performance. It is expected that using new information technologies such as social media will enable the firm to act proficiently on business opportunities and reconfigure human resources by utilizing networks to routinize the business's knowledge and innovation competencies. This study aims to examine how different purposes of social media use to influence employees' level of job performance directly or indirectly through job satisfaction as a mediator. Two purposes are identified: work-related purposes and personal purposes. A closed questions survey tool was used to gather the data from the employees of three leading organizations in the Tulkarm district. Two hundred eighty-two valid questionnaires were analyzed using SPSS and IBM SPSS Amos 24. The findings revealed that the impact of using social media for work purposes on job performance is fully mediated by job satisfaction, while social media use for personal purposes does not influence job performance directly nor indirectly. The current study enriches the available literature by examining social media use from two perspectives: work-related and personal purposes, thus added value to the available literature, particularly in the Palestinian context. Practically, managers could benefit from the work by adopting relevant strategies to guide this use in a way that motivate the employees towards achieving the goals of the organizations. Such as offering reliable internet services which may help in encouraging the employees or even attracting the ones who are not engaged yet in social media to start using it for work purposes, as for personal purposes, specific policies can be adopted to monitor this use within controls. The article recommends organizations to utilize and direct social media use for work purposes towards achieving the goals of the organizations.

Keywords: communication, job satisfaction, performance, personal purposes, social media.

Introduction. Using social media has added new value for organizations and business development. It changes the way people communicate, shares knowledge, exchange ideas. According to Brand watch (2019), 81\% of all small and medium businesses use some kind of social platforms in their operations. The concept of using social networking at the workplace is a controversial issue. The supporters argue that the use of social media improves the performance of employees directly or through mediator variables such as job satisfaction, morality, and commitment (Leidner et al., 2010; Kaplan and Haenlein, 2010; Charoensukmongkol, 2015; Carlson et al., 2016; Alalwan et al., 2017). One of the most important studies that supported the significant role of using social media at the workplace in improving workers' job performance is Moqbel et al. (2013) which found that social media use by organizational members leads to enhance job performance through the mediation role of job satisfaction. Similarly, Cao and Ali (2018) indicated that using social media in the workplace is positively related to job performance. It seems that

Cite as: Alkhateeb, M., \& Abdalla, R. (2020). Innovations in Human Resource Management: Impact of Social Media Use on Employees' Performance. Marketing and Management of Innovations, 2, 139-153. http://doi.org/10.21272/mmi.2020.2-10 
using social media removes the obstacles in collaboration by creating a sharing work environment and enhancing job satisfaction that yields improvement in job performance (Munene and Nyaribo, 2013).

On the other hand, several researchers claim that social media use at the workplace leads to a negative impact on employees' performance (Bevan et al., 2014; Fox and Moreland, 2015; Moqbel and Kock, 2018; Yu et al., 2018). They claim that intensive use of social media at workplace may lead to adverse outcomes, such as addiction, time waste, low level of positive emotions, poor health, and low performance (Moqbel and Kock, 2018; Fox and Moreland, 2015). Cao and Yu (2019) indicated that although the use of social media is influencing positively technology-work conflict and negatively strain, both of them harm job performance. Overall, it was evident that the debate over the influence of social media use has not yet been settled (Mogbel and Kock, 2018).

Social media is a broad term that involves a wide range of applications and tools; however, there are several standard features related to those tools. First, the tools are technology-based usually used by employees and influence the organization; second, they are commonly social and used to support interaction among people; finally, these tools are used at work as well as for personal contacts (Ali-Hassan et al., 2015).

Recently, social media platforms have been used increasingly in the workplace to facilitate communications among employees (Leonardi et al., 2013; Jafar et al., 2019). Social media platforms provide essential benefits to knowledge management as it enhances both vertical and horizontal communication (Mantymaki and Riemer, 2016). Firms now consider social media as a strategic tool to spur innovation, and a large number of them have integrated social media into their operation system (Lam et al., 2016).

Also, there is a growing number of academic articles concerning social technology, the existing literature in this field indicated that few studies investigated the use of social media in organizations settings (El Ouirdi et al., 2015). According to Shujaat et al. (2019), the majority of these studies have been conducted in educational institutions. Few studies that are corporate-related concentrated on external use rather than internal use. Thus, this study aims to fill the gap in the literature by examining the influence of using social media on employees' performance directly and through conditional factors. Besides, little research studied the impact of using social media on work outcomes in different cultures. Therefore, there is a need to investigate the findings of these studies in other cultures (Moqbel and Aftab, 2015). The current study argues that social media in organizations facilitate communication, knowledge sharing, and exchange ideas that may lead to high mortality, positive attitudes, and job satisfaction, which in turn improves employees' performance. However, and since the terms job satisfaction, job attitude, and morale are usually used interchangeably, and they measure the same concept as reported by (Mogbel et al., 2013), job satisfaction variable will be used as a mediator to explore the relationship between the use of social media and job performance.

Literature review. Plenty of existing research has investigated the influence of using social media on individual attitudes, but empirical research on using social media at work is minimal (Leftheriotis and Giannakos, 2014). Besides, the debate on social media has focused on the dark side linked with using it at the workplace. Holland et al. (2016) argued that there is much need to explore the opportunities in using social media to improve the relationships between the employer and the employees and consequently increases employees' engagement and organizational effectiveness. Ashraf and Jeved (2014) provided evidence that using social networking at the workplace in banking sector significantly and positively influence the employees' performance through its effect on their skills, knowledge, productivity and motivation level. Despite that the usage of social media at the workplace has been widely investigated by researchers, most of the past studies concentrated on the work-related aspect and neglected the use of social media for personal purposes (Zhang et al., 2019). In this study, both dimensions of social media use will be studied. 
M. Alkhateeb, R. Abdalla. Innovations in Human Resource Management: Impact of Social Media Use on Employees' Performance

Social media use and job satisfaction. Job satisfaction is of significant concern for organizations. It is because job satisfaction could lead to better job performance (Moqbel, 2012). Job satisfaction can be defined as the positive feeling that an individual experiences as a result of his judgment on his job experience (Locke, 1976). Researchers agree that human resources are the most crucial assets for their organizations and that employees who are unsatisfied with their jobs tend to demonstrate negative behaviours (Charoensukmongkol, 2015).

Limited studies have investigated the influence of social media use on job satisfaction at the workplace. For instance, a study by (Robertso and Kee, 2017) investigated the impact of using social media on workers' satisfaction in various organizations in Southern California. The results showed that job satisfaction is positively associated with the intensity of the use of Facebook. Charoensukmongkol (2014) argued that using social media at work help employees to feel relaxed and remove workstress as it allows them to connect with their families and colleagues, which in turn enhances job satisfaction. Similarly, Demircioglu and Chen (2019) conducted a study to analyze the influence of using social media for workrelated purposes on public sector employees, the findings revealed that employees' use of social media is positively related to employees' needs satisfaction and, ultimately, intrinsic motivation. Demircioglu (2018) reported a strong positive influence of using social media for work purposes on employee's job satisfaction but through self-determination. Barnett et al. (2019) argued that using social media for work purposes increases employees' job satisfaction. Surveying 298 employees in China, Zhang et al., (2019) found that the use of social media for both work-related and non-work-related purposes is positively associated with job satisfaction. Hayes et al., (2017) used McAfee's argument to examine whether a positive connection between work colleagues exist as a result of using Facebook to connect, the findings showed that employees' level of job satisfaction is positively correlated with Facebook intensity use among colleagues. Alahmad et al. (2018) investigated the influence of enterprise social media (ESM) on job satisfaction and job performance through co-workers support as a mediator. The findings revealed that ESM significantly and positively impacts co-worker support, which in turn mediates the relationship between ESM and job satisfaction and job performance.

Social media and job performance. Job performance could be defined as the overall job-related activities expected from an employee and how well they are accomplished (Cao, 2010). Research suggests that using social media in the workplace may lead to improve employees' job performance (Shujaat et al., 2019).

Moqbel et al. (2013) found that excessive use of social media at the workplace was positively related to job performance through the mediating effect of job satisfaction. Pitafi et al., (2018) investigated how the usage of enterprise social media (ESM) influences employees' performance through task interdependence, the results confirmed the significant positive impact of such ESM of employees' performance. Similarly, the study conducted by Shujaat et al. (2019) revealed that social media use at the workplace is not directly associated with employee job performance but through the mediating effects of job satisfaction. Utilizing media synchronicity theory to investigate the association between using social media and job performance, Charoensukmongkol (2014) found that the heavy use of social media at the workplace is directly associated to job satisfaction and job performance. A study by Zhang and Venkatesh (2013) on the implication of social media on job performance revealed that social media has a positive impact on employee job performance. Additionally, Haddud et al., (2016) demonstrated that the more significant employees' self-reported usage of internal social media, the higher the level of employees' selfreported engagement, which in turns may lead to a higher level of employees' job performance.

On the other hand, several scholars argued that using social media at the workplace presents several risks for employees and organizations (El Ouirdi et al., 2015). For example, Brooks and Califf (2017) defined the term Technostress as the direct negative influence on behaviours, attitudes, thoughts, or physiology that results from using technology. They examined the direct influence of social media-related 
Technostress during work hours on the employees' job performance, a direct negative significant influence was reported. Similarly, Cao and Yu (2019) argued that intensive use of social media for socialization could create conflict between technology use and work demand. Brooks (2015) found that higher amounts of personal social media usage may lead to a high level of Technostress and low level of happiness and untimely negative impact on task performance. Additionally, using social media at the workplace is considered as time-wasters (Turban et al., 2011).

On the other hand, Song et al. (2019) examined the synergistic effect of social media common usage (work-oriented and socialization-oriented) on team and employees' performance. The findings of their study showed that both purposes of social media usage are complementary resources that create synergies to enhance team and employees' performance.

The nature of the relationship between job satisfaction and employee performance is still unresolved and needs further investigation (Shujaat et al., 2019). Roberts and David (2020) argued that when people are in favour of a confident attitude, they are most likely to behave inconsistently with predispositions. Therefore, it is logical to conclude that in the workplace context, job satisfaction is positively linked to the high level of performance. Similar to this argument, Fisher (2003) suggested that ordinary people believe satisfied employees perform better than less happy ones. Examining the relationship between job satisfaction and job performance of the university librarians, Peng (2014) found that both intrinsic and extrinsic job satisfaction contributed to the librarians' expected level of task performance and contextual performance. Bin (2015) confirmed the positive impact of job satisfaction on employees' performance and stated that satisfied employees are a great asset to their organizations and contribute to overall goals and success of an organization.

Methodology and research methods. Consequently, the following hypotheses are proposed:

$\mathrm{H}$ 1: Using social media at the workplace for work purposes positively influence employees' job satisfaction.

H2: Using social media at the workplace for personal purposes positively influence employees' job satisfaction.

Therefore, there is a need for more analysis to explore the nature of the relation between the use of social media and employees' job performance despite the prevalence of social media. Consequently, the following hypotheses are proposed:

$\mathrm{H} 3$ : Using social media at the workplace for work purposes positively influence employees' job performance.

$\mathrm{H} 4$ : Using social media at the workplace for personal purposes positively influence employees' job performance.

H5: Using social media at the workplace for work purposes positively influences employees' job performance through job satisfaction.

H6: Using social media at the workplace for personal purposes positively influence employees' job performance

On the other hand, there is research indicated that job satisfaction is not necessar ily lead to better performance of employees. Based on this discussion, the following hypotheses were developed:

$\mathrm{H} 7$ : Job satisfaction has a positive and direct impact on job performance.

Figure 1 shows the proposed research model. 
M. Alkhateeb, R. Abdalla. Innovations in Human Resource Management: Impact of Social Media Use on Employees' Performance

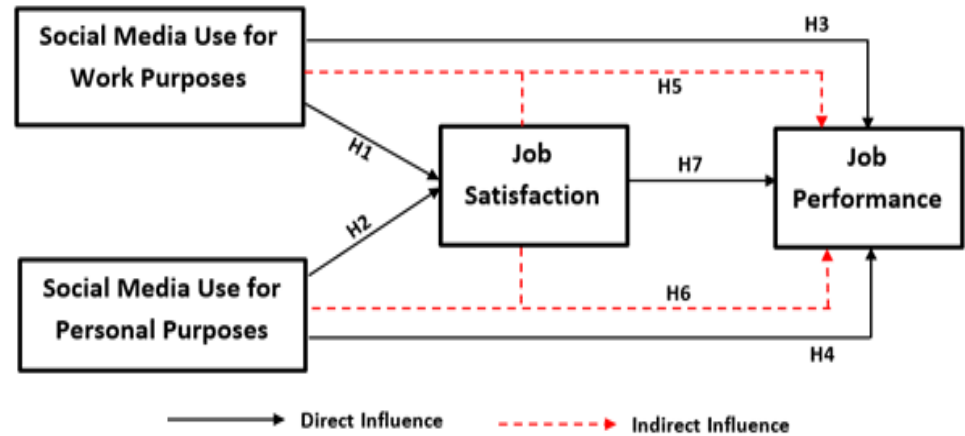

Figure 1. The proposed research model

Source: developed by the authors.

The data used for this study were collected from three of the largest organizations in the Tulkarm district. A survey was developed based on previous literature. Some of these questions were modified to fit the current study. All questionnaire items were assessed using a five-point Likert scale. To measure the validity of the questionnaire items, a pilot test was conducted on a group of 20 individuals, including three researchers in the same field and 17 students from business school. The results of the pilot test were used to finalize the questionnaire items. Questionnaires were distributed to the targeted employees for 25 days. The total number of the respondents was 305 , twenty-three of them were excluded because they were invalid, yielding 282 valid questionnaires for analysis.

Measures. The constructs shown in Figure 1 were measured using items derived from previous literature. As for the use of social media for work purpose, the items were borrowed from Gonzalez et al. (2013). Regarding the use of social media for personal use, the items were adapted from Zhang et al. (2019). Job satisfaction was measured using the modified scale that was developed by Mogbel and Aftab (2015). Finally, job performance was measured using four items; two from Mogbel and Kock (2018) and two from Moqbel et al. (2013) measures.

The study considered four of the most common social media sites in Palestine, including Facebook, Twiter, Instagram, and WhatsApp. Besides, the internal network within the company was considered as a fifth option, and finally, other networks option was included. The respondents could choose all the networks that he uses.

To analyze the data, the researchers used SPSS for demographic data analysis, and IBM SPSS AMOS 24.0 to test the proposed model and the hypotheses.

Results. Table 1 summarizes the demographic characteristics of the respondents.

Table 1. Demographic characteristics

\begin{tabular}{cccc}
\hline Demographic Category & Classification & Frequency & Percent \% \\
\hline Gender & Male & 167 & .592 \\
& Female & 115 & 40.8 \\
\multirow{2}{*}{ Age } & Total & 282 & 100.0 \\
& $18-27$ Years & 80 & 28.4 \\
& $28-37$ Years & 98 & 34.8 \\
& $38-47$ Years & 85 & 30.1 \\
& $48-57$ Years & 16 & 5.7 \\
& $>50$ Years & 3 & 1.1 \\
& Total & $\mathbf{2 8 2}$ & 100.0 \\
\hline
\end{tabular}


M., Alkhateeb, R., Abdall. Innovations in Human Resource Management: Impact of Social Media Use on Employees' Performance

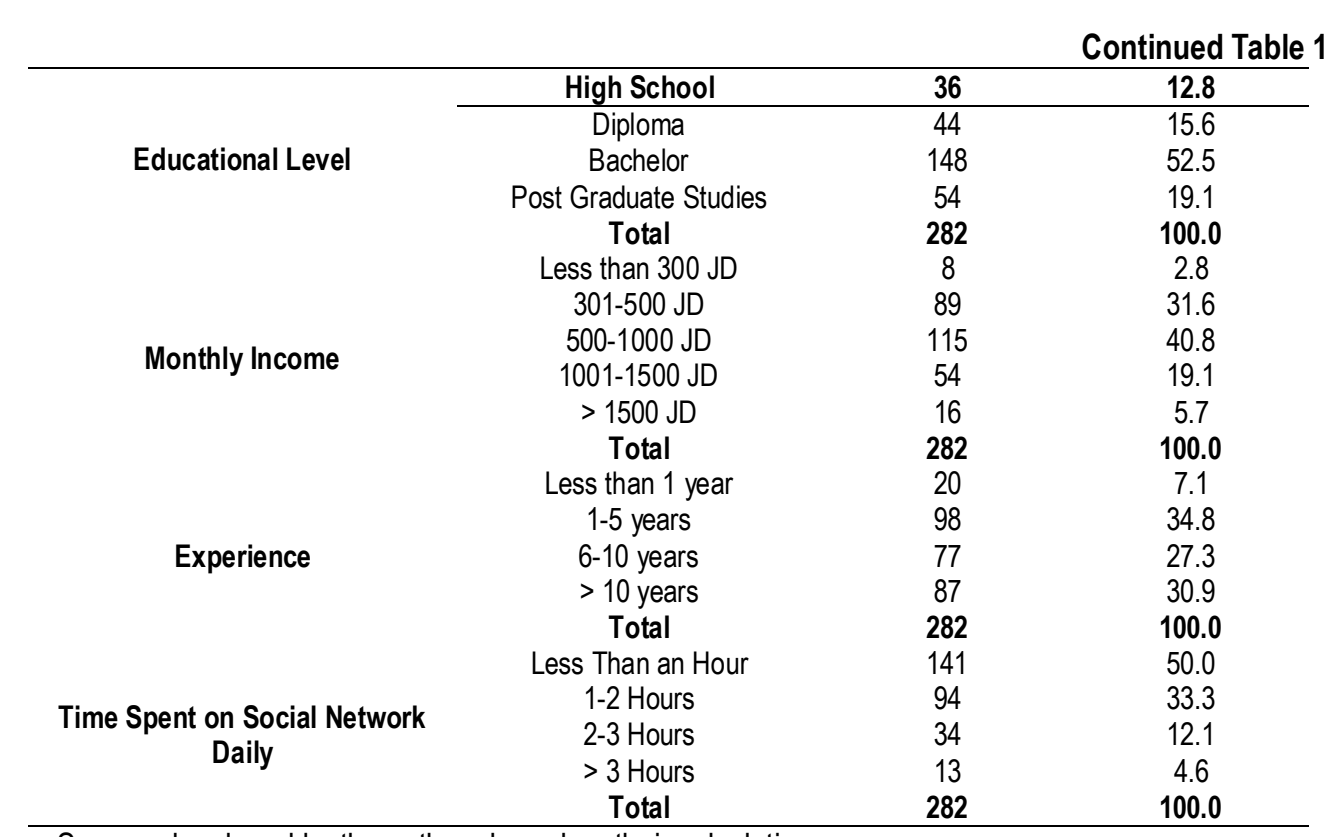

Source: developed by the authors based on their calculations

As Table 1 illustrates, the study sample was made up of $59.2 \%$ males and $40.8 \%$ females, where $64.9 \%$ of the respondents within the age groups of (28-37 and 38-47 years), followed by age group (18-27 years) forming $28.4 \%$, then (48-57 years) with $5.7 \%$ and last came to the age group (>57 years) with $1.1 \%$. In regards to the educational level of the surveyed employees, the majority (52.5\%) are Bachelor degree holder, next came the Post Graduate Degree holders with 19.1\%, then Diploma Degree holders (15.6\%), and High School Certificate holders $(12.8 \%)$. Concerning the monthly income, the highest percentage was for the category of (500-100 JD) forming 40.8\%, where the lowest percentage was $(5.7 \%)$ for the category $(>1500$ JD). As for the experience of the participants, $34.8 \%$ of them have an experience of (1-5 years), 30.9\% have and experience more than ten years, $27.3 \%$ have (6-10 years) experience, and lastly, $7.1 \%$ have a little experience of less than one year. Half of the study sample spend less than an hour daily on social networks, followed by those who spend about 1-2 hours per day forming 33.3\%, next who spend about 2-3 hours with $12.1 \%$, finally heavy users who spend more than three hours daily on social networks formed $4.6 \%$. The number of users/nonusers of each network is shown in Figure 2.

As shown in Figure 2, Facebook has the highest number of users of 213, next comes WhatsApp with 208 users, followed by Instagram with 81 users, then 70 users use the internal network in their companies, next Twiter with 67 users and last came 26 users who use another network. Path Loading (Confirmatory Factor Analysis). The current study adopted Anderson and Gerbing (1988) approach. First, Confirmatory Factor Analysis (CFA) is conducted and enhanced as poor CFA's yields poor models, and next structured equation model is conducting for hypotheses testing. CFA is the most commonly used multivariate technique to assess measures' validity. IBM SPSS Amos provides many goodness-of-fit statistics that can be used to determine how well the implied variance-covariance matrix of the research model corresponds to the observed variance-covariance matrix. Besides, CFA allows error variance modelling (Marsh et al., 2014, p.86). To assess the goodness of fit of the CFA, Catalsakal $(2016, p$. 49) indicated that the following indices are considered: chi-square to the degree of freedom ratio; Adjusted Goodness of Ft Index (AGFI); Goodness of Fit Index (GFI); Comparative Fit Index (CFI); and Root Mean Square Error of Approximation (RMSEA). 
M. Alkhateeb, R. Abdalla. Innovations in Human Resource Management: Impact of Social Media Use on Employees' Performance

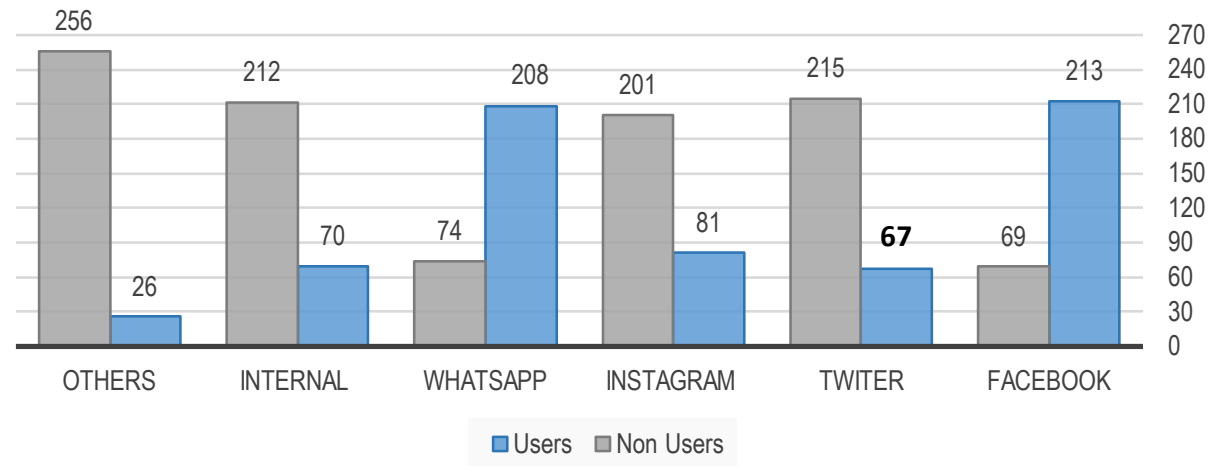

Figure 2. Social media sites users' numbers

Source: developed by the authors

As a preliminary stage, the path loadings of the variables were calculated using CFA. Figure 3 depicts the loadings of the initial CFA.

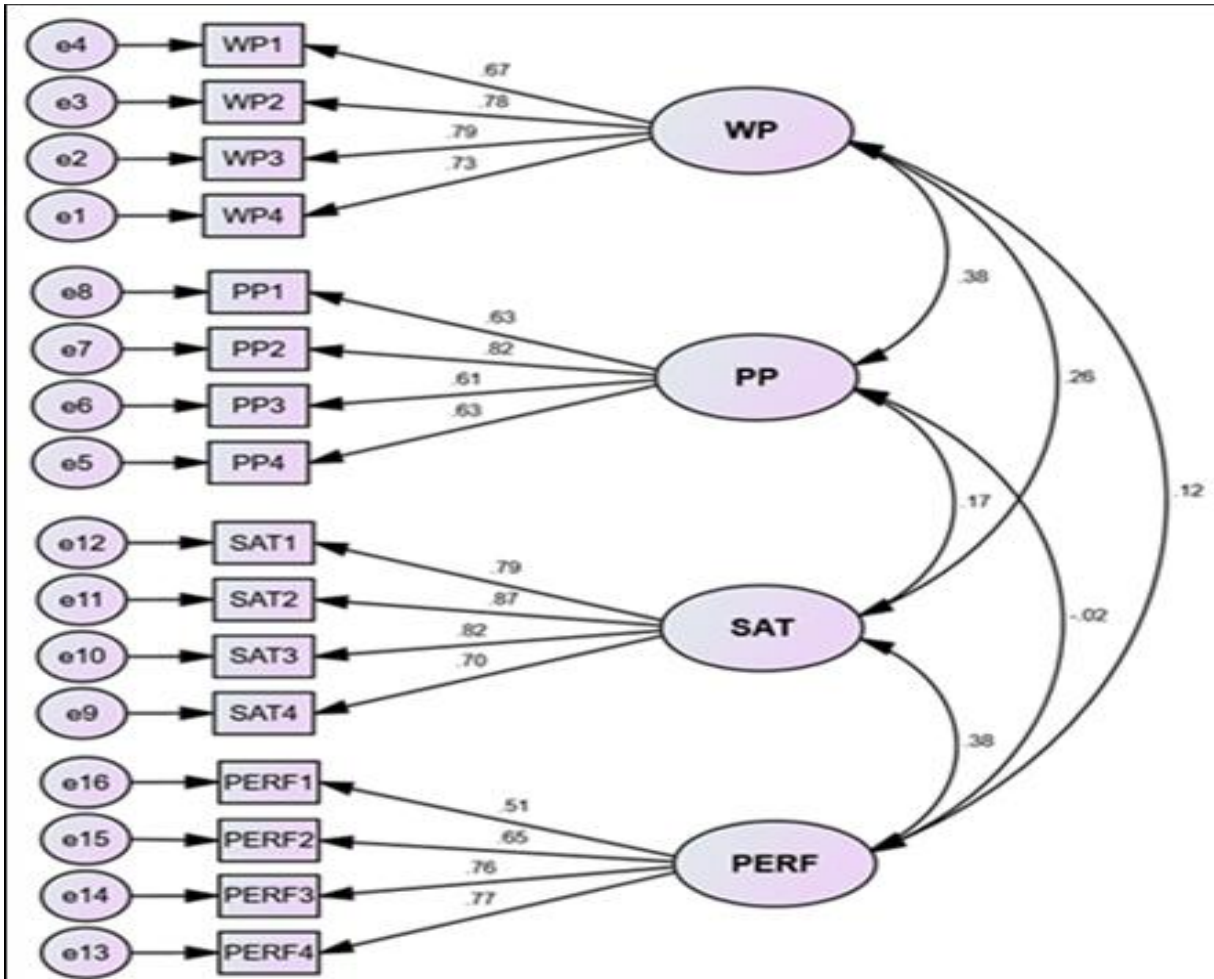

WP: Work Purposes ; PP: Personal Purposes; SAT: Job Satisfaction PERF: Job Performance

Figure 3. CFA of the initial proposed model

Source: developed by the authors 
M., Alkhateeb, R., Abdall. Innovations in Human Resource Management: Impact of Social Media Use on Employees' Performance

All path loadings are above or equal the cut off value of 0.6 (Hair et al., 2006) except for the loading of PERF1, which is 0.51 . Therefore this factor was removed. The path loading of the new model is shown in Figure 4.

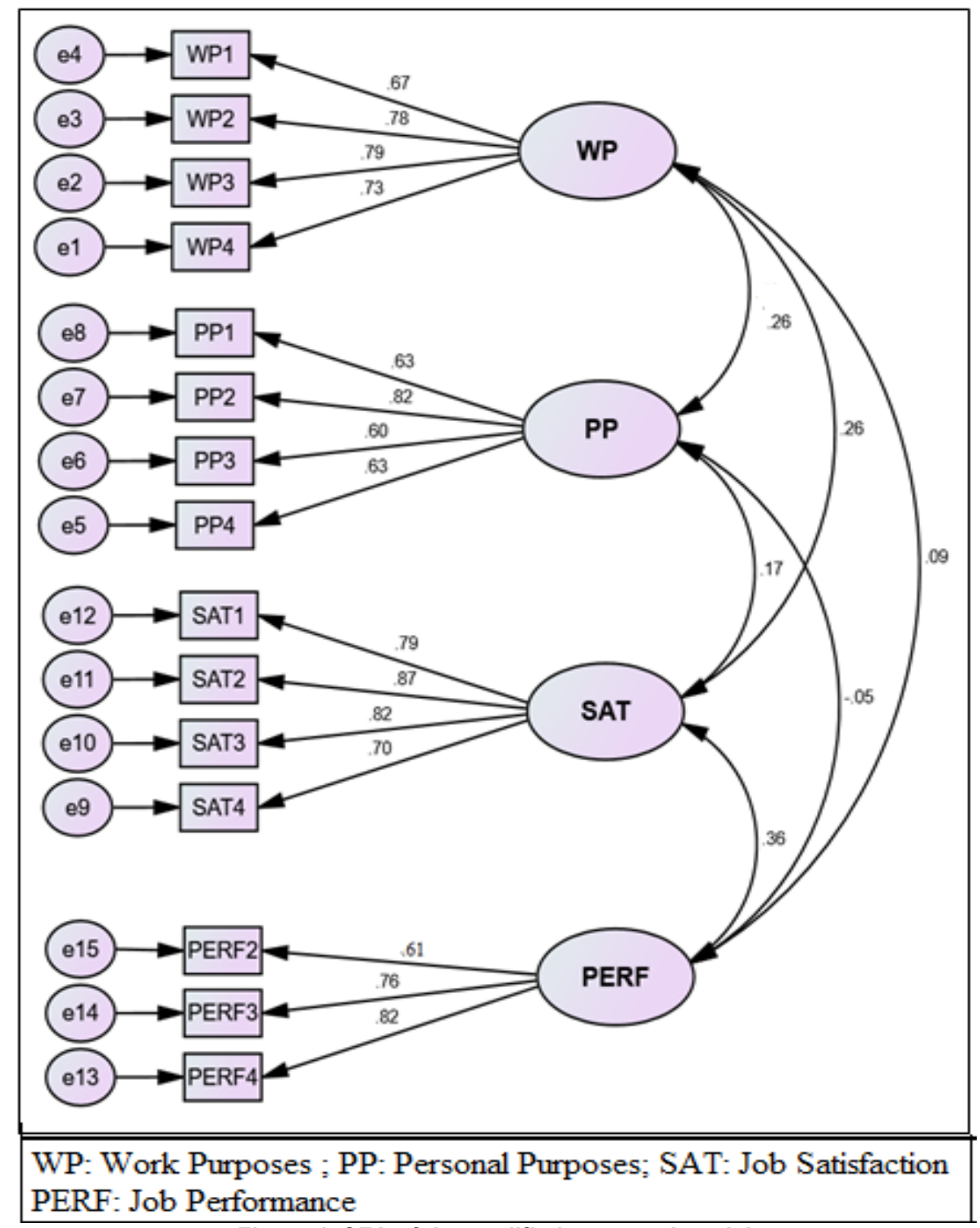

Figure 4. CFA of the modified proposed model

Source: developed by the authors

The goodness of fit indicators of the modified CFA are as follows: (GFI $=0.935)$; (AGFI=0.907); $(\mathrm{CFI}=0.959) ;(\mathrm{TLI}=0.948) ;(\mathrm{RMSEA}=0.053) ;$ and $\left(\chi^{2 / d f=1.79)}\right.$. All of these values are within the acceptable thresholds (Walker and Maddan, 2013). 
M. Alkhateeb, R. Abdalla. Innovations in Human Resource Management: Impact of Social Media Use on Employees' Performance

Reliability and Validity of the Constructs. Table 2 lists the values of reliability and validity measure of the study constructs. All of the study constructs have Cronbach Alpha values that exceed the cutoff value of 0.7 (George and Mallery, 2003), Composite Reliability values are higher than 0.7 indicating a right level of reliability (Hair et al., 2014). The average variance extracted (AVE)is a measure of convergent validity, a value of 0.5 or higher is accepted (Fornell and Larcker, 1981). A value of 0.5 indicates that the construct explains half the variance of its items. The AVE values of all constructs are above 0.5 except for PP construct where the value is .46 , which is tolerable. CR and AVE values were calculated using (George, 2016) statistical tools.

Table 2. Cronbach Alpha CA, Composite Reliability CR, and AVE values

\begin{tabular}{cccc}
\hline Construct & CA & CR & AVE \\
\hline WP & 0.83 & 0.83 & 0.55 \\
PP & 0.77 & 0.78 & 0.46 \\
SAT & 0.87 & 0.88 & 0.64 \\
PERF & 0.77 & 0.78 & 0.54 \\
\hline
\end{tabular}

Source: developed by the authors based on their calculations

Structured Equation Modeling (SEM). Structural Equation Modelling is a comprehensive method in testing direct and indirect relationships between one or more independent variables and one or more dependent variables. The SEM of the current study is depicted in Figure 5.

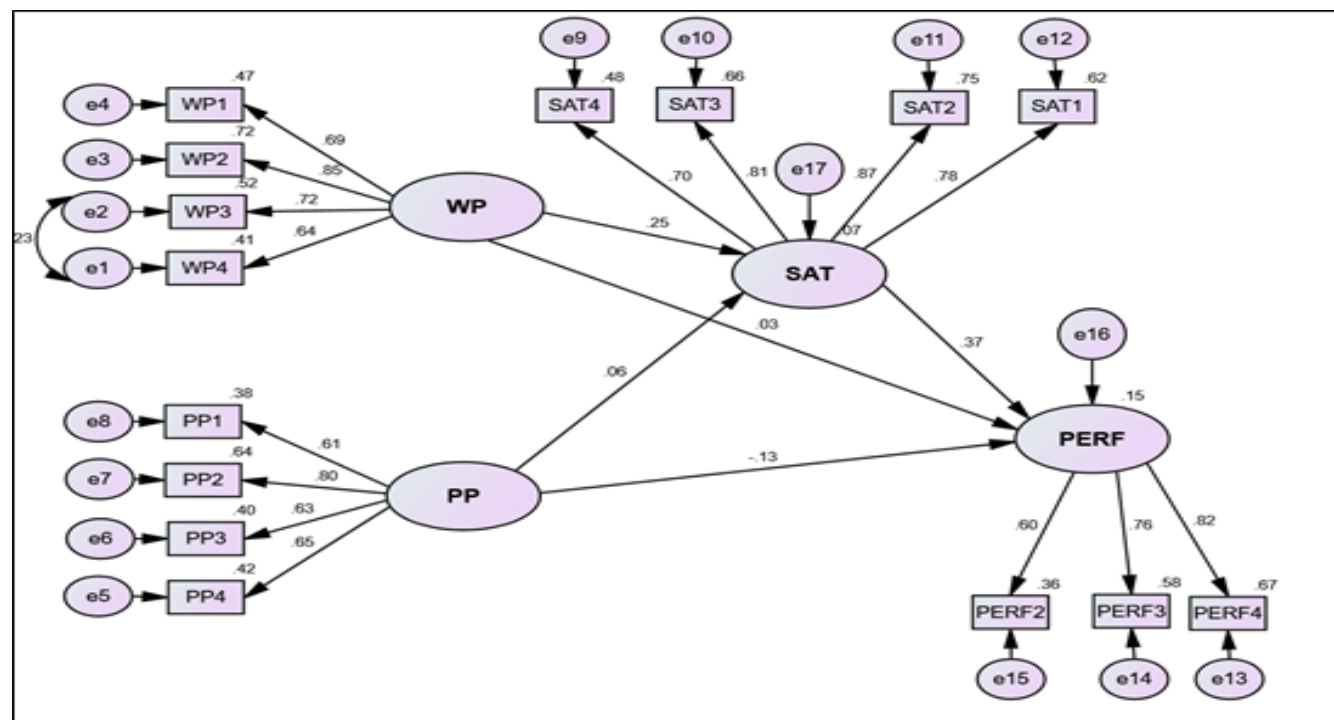

WP:Work Purposes; PP:Personal Purposes; SAT: Job Satisfaction; PERF: Job Performance

Figure 5. Structural Equation Model of the study

Source: developed by the authors

Figure 5 shows four constructs: WP and PP represent the exogenous (independent) constructs, each of them in loaded by four items; SAT is the mediator construct loaded by four items; and PERF as the endogenous (dependent) construct that is loaded by three items. The indicators of goodness of fit are listed in Table 3. 
M., Alkhateeb, R., Abdall. Innovations in Human Resource Management: Impact of Social Media Use on Employees' Performance

Table 3. The indicators of goodness

\begin{tabular}{ccc}
\hline Index of Fit & Acceptance Level $^{*}$ & Findings $^{*}$ \\
\hline GFI & $>0.9$ & .916 \\
AGFI & $>0.9$ & .880 \\
CFI & $>0.9$ & .921 \\
TLI & $>0.9$ & .902 \\
RMSEA & $<0.08$ & 0.07 \\
$\chi^{2 / d f}$ & $<5$ & 2.52 \\
\hline
\end{tabular}

Source: Walker and Maddan (2013).

Direct Influences and Hypotheses Testing. The direct influence between the constructs is summarized in Table 4.

Table 4. The results of the direct relationship

\begin{tabular}{cccc}
\hline Direct Influence & Standardized Coefficient $(\boldsymbol{\beta})$ & P-value & Hypotheses Testing Result \\
\hline WP on SAT & 0.250 & 0.006 & H2 is supported \\
WP on PERF & 0.030 & 0.724 & H4 is not supported \\
PP on SAT & 0.064 & 0.520 & H1 is not supported \\
PP on PERF & -0.125 & 0.082 & H3 is not supported \\
SAT on PERF & 0.372 & 0.002 & H7 is supported \\
\hline
\end{tabular}

Source: developed by the authors based on their calculations

Table 4 illustrates that social media use for work purposes (WP) has a positive direct significant influence on job satisfaction as the $p$-value is $<0.05$ with a standardized coefficient weight $(\beta=0.250)$. Thus, $\mathrm{H} 2$ is supported. On the other hand, WP has no significant direct influence on job performance, as the $\mathrm{p}$ value is more significant than the significance level of 0.05 . Therefore, $\mathrm{H} 4$ is not supported. Regarding social media use for personal purposes (PP), the results revealed no significant direct influence on both job satisfaction and job performance as the $\mathrm{p}$-value exceeds 0.05 significance level. As a result, $\mathrm{H} 1$ and $\mathrm{H} 3$ are not supported. For the relationship between job satisfaction and job performance, a direct positive significant influence is depicted with $(\beta=0.372)$ and a $p$-value $<0.05$, hence $\mathrm{H} 7$ is supported. It implies that as the level of satisfaction of the employees with their job increases, their performance with their jobs will be better. Based on Preacher and Hayes (2004) and Hayes (2017) arguments, Although that there is no significant direct effect of WP and PP on PERF, it is still legitimate to assess the role of SAT as a mediator between WP and PP as independent constructs on one side and PERF as dependent construct on the other side. Therefore, the next step is to assess the indirect influences. Direct and Indirect Influences. In order to find the indirect influence of the exogenous variables (WP and PP) and endogenous variable (PERF) through job satisfaction as a mediator, bootstrapping technique was conducted. Table 5 , and Table 6 lists the findings related to each of the exogenous variables.

Table 5. Direct and Indirect Influence of WP on PERF

\begin{tabular}{|c|c|c|c|c|c|c|}
\hline Relation & $\begin{array}{c}\text { Direct } \\
\text { influence }(\beta)\end{array}$ & $\begin{array}{l}\text { P-value } \\
\text { for direct }\end{array}$ & $\begin{array}{l}\text { Indirect } \\
\text { influence } \\
(\beta)\end{array}$ & $\begin{array}{l}\text { P-value } \\
\text { for } \\
\text { indirect }\end{array}$ & $\begin{array}{c}\text { Total } \\
\text { Influence }\end{array}$ & $\begin{array}{l}\text { Hypotheses } \\
\text { Testing Result }\end{array}$ \\
\hline WP on SAT & 0.250 & 0.006 & - & - & 0.250 & H5 Supported \\
\hline SAT on PERF & 0.372 & 0.002 & - & - & 0.372 & \\
\hline WP on PERF with & Fully Mediated & & 0.094 & 0.005 & & \\
\hline $\begin{array}{l}\text { SAT as a } \\
\text { mediator }\end{array}$ & & & & & & \\
\hline WP on PERF & 0.030 & 0.724 & & & 0.124 & \\
\hline
\end{tabular}

Source: developed by the authors based on their calculations 
M. Alkhateeb, R. Abdalla. Innovations in Human Resource Management: Impact of Social Media Use on Employees' Performance

Table 5 shows that job satisfaction fully mediates the relationship between WP and PERF with $(\beta=0.0 .093)$ and $p$-value of 0.005 . It leads to support $H 5$. The total effect of WP on PERF is 0.123 , which means that job satisfaction as a mediator has enhanced the total influence of WP on PERF. To m easure the strength of mediation, Hair et al. (2014) suggested using variance accounted for VAF (indirect effect/total effect ${ }^{*} 100 \%$ ). In the current study, $76 \%$ of the influence of WP on PERF is explained through the SAT.

Table 6. Direct and Indirect Influence of PP on PERF

\begin{tabular}{|c|c|c|c|c|c|c|}
\hline Relation & $\begin{array}{c}\text { Direct } \\
\text { influence } \\
(\beta)\end{array}$ & $\begin{array}{c}\text { P-value } \\
\text { for } \\
\text { direct }\end{array}$ & $\begin{array}{c}\text { Indirect } \\
\text { influence } \\
(\beta)\end{array}$ & $\begin{array}{l}\text { P-value } \\
\text { for } \\
\text { indirect }\end{array}$ & $\begin{array}{c}\text { Total } \\
\text { Influence }\end{array}$ & $\begin{array}{l}\text { Hypotheses } \\
\text { Testing Result }\end{array}$ \\
\hline PP on SAT & 0.064 & 0.520 & & & & \\
\hline SAT on PERF & 0.372 & 0.002 & - & - & 0.372 & \\
\hline $\begin{array}{c}\text { PP on PERF } \\
\text { with SAT as a } \\
\text { mediator }\end{array}$ & $\begin{array}{c}\text { Not } \\
\text { mediated }\end{array}$ & - & 0.024 & 0.483 & & $\begin{array}{c}\text { H6 Not } \\
\text { Supported }\end{array}$ \\
\hline PP on PERF & -0.130 & 0.082 & & 0.189 & -0.106 & \\
\hline
\end{tabular}

Source: developed by the authors based on their calculations

Table 6 shows that job satisfaction does not mediate the relationship between PP and PERF. This result is expected since PP has no direct influence on the SAT. Therefore, PP does not influence PERF, either directly or indirectly. The use of social media is prevalent in workplaces today (Grimmelikhuijsen and Meijer, 2015). It is expected that using social media by employees at the workplace will improve their performance. Although that the existing research investigated the effects of social media on individuals and organizations outcomes, still how employees' use of social media for personal and work purposes affects their work performance should be investigated in depth. The findings of this study regarding the direct influences show that social media use for work purpose has no direct impact on job performance. This result matches the findings of Shujaat et al. (2019) and Mogbel and Aftab (2015) while contradicts Cao and Ali (2018) and Charoensukmongkol (2015). On the other hand, it positively influences job satisfaction, which is in line with the findings of Demircioglu and Chen (2019), Demircioglu (2018) and Robertso and Kee (2017). Concerning the use of social media for personal purpose, the findings revealed no direct influences on both job satisfaction and job performance, which is in contrast with Brooks and Califf (2017) and Zhang et al. (2019). For the relationship between job satisfaction and job performance, significant direct influence is noted. This result confirms earlier work findings of Shujaat et al. (2019); Bin (2015); Mogbel and Aftab (2015). Relating to the indirect influences, the results showed that social media use for work purposes has significant indirect influence (through job satisfaction as a mediator) on job performance. The relationship between social media use for work purposes, and job performance was fully mediated by job satisfaction. This result goes with the findings of Shujaat et al. (2019), while it contradicts Moqbel and Aftab (2015) and Moqbel et al. (2013) findings. As for the indirect relationship between social media use for personal purposes on job performance through job satisfaction as a mediator, no such an indirect influence was depicted.

Conclusions. Overall, the results of these articles confirmed the argument that social media use during work hours influences employees' job satisfaction and job performance. Although that social media use for work purposes does not influence employees' job performance directly, it enhanced the employees' level of job satisfaction, this could be attributed to their ability to share, discuss, and easily exchange workrelated materials, which in turn helps in performing some activities more efficiently. Ultimately, a higher level of employees' job satisfaction results in a higher level of job performance as this study has shown. The other side of the coin is the use for personal purposes, which had no significant influence on job 
satisfaction, a possible justification for this is that the employees may feel overloaded with information while they are using social media for personal purposes particularly that they have work responsibilities. It may induce the level of stress and thus reduce the level of job satisfaction and hence job performance. Besides, the quality of friendship in social media plays a critical role in supporting the employees either positively, which enhances job performance, or negatively thus reducing job performance level. In conclusion, the findings suggest that social media use for work purposes is an essential element in improving job performance through the mediating role of job satisfaction. Theoretically, the current study has contributed to our understanding of the impact of using social media for different purposes at the workplace. It is one of the few studies that examined the relationships between social media use purposes and job performance. Although that previous work has examined this relationship, this paper examined it from two perspectives: work-related and personal purposes, thus added value to the similar few studies available in the literature, particularly in the Palestinian context. The use of social media for work-related purposes could be considered as a motivator for employees' job satisfaction that might lead to a better level of job performance. Practically, this paper provides evidence that technology implemented in social media use at the workplace is beneficial in the work environment. The results indicated that social media use for work purposes improves employees' job performance through job satisfaction. Therefore, the managers could benefit from adopting strategies that guide this use and motivate the employees towards achieving the goals of the organizations. Offering reliable internet services may help in encouraging the employees or even attracting the ones who are not engaged in social media use yet to start using it to share work-related materials with colleagues. The lack of significance between social media use for personal purposes on employees' job satisfaction, and job performance supports the argument that this use is not necessarily against employees' performance as thought to be. If organizations tried to prohibit this use during work hours, this might enforce the employees to secretly stay in contact with their families and friends by using their mobile phones. It is suggested that organizations should not prohibit this use because of its psychological benefits in reducing employees' anxiety level over their families and easing work pressures, instead, policies can be adopted to use it with in controls.

Author Contributions: conceptualization, M. A. and R. A.; methodology, M. A.; software, R. A.; validation, M. A. and R. A.; formal analysis, R. A.; investigation, M. A; resources, M. A. and R. A; data curation, R. A.; writing-original draft preparation, M. A.; writing-review and editing, M. A. and R. A.; visualization, R. A.; supervision, M. A.; project administration, M. A.

Funding: This research received no external funding.

\section{References}

Alahmad, R., Carter, M., Pierce, C., \& Robert, L. (2018). The impact of enterprise social media identity on job performance and job satisfaction. 24th Americas Conference on Information Systems. [Google Scholar]

Alalwan, A. A., Rana, N. P., Dwivedi, Y. K., \& Algharabat, R. (2017). Social media in marketing: A review and analysis of the existing literature. Telematics and Informatics, 34(7), 1177-1190. [Google Scholar] [CrossRef]

Ali-Hassan, H., Nevo, D., \& Wade, M. (2015). Linking dimensions of social media use to job performance: The role of social capital. The Journal of Strategic Information Systems, 24(2), 65-89. [Google Scholar] [CrossRef]

Anderson, J. C., \& Gerbing, D. W. (1988). Structural equation modeling in practice: A review and recommended two-step approach. Psychological bulletin, 103(3), 411. [Google Scholar]

Ashraf N., \& Javed, T (2014). Impact of social networking on employee performance. Business Management and Strategy, 5(2), 139-150. [Google Scholar]

Barnett, M. D., Martin, K. J., \& Garza, C. J. (2019). Satisfaction with work-family balance mediates the relationship between workplace social support and depression among hospice nurses. Journal of Nursing Scholarship, 51(2), 187-194. [Google Scholar] [CrossRef]

Bevan, J. L., Gomez, R., \& Sparks, L. (2014). Disclosures about important life events on Facebook: Relationships with stress and quality of life. Computers in Human Behavior, 39, 246-253. [Google Scholar] [CrossRef]

Brooks, S. (2015). Does personal social media usage affect efficiency and well-being?. Computers in Human Behavior, 46, 2637. [Google Scholar] [CrossRef] 
M. Alkhateeb, R. Abdalla. Innovations in Human Resource Management: Impact of Social Media Use on Employees' Performance

Brooks, S., \& Califf, C. (2017). Social media-induced Technostress: Its impact on the job performance of it professionals and the moderating role of job characteristics. Computer networks, 114, 143-153. [Google Scholar] [CrossRef]

Caillier, J. G. (2010). Factors affecting job performance in public agencies. Public Performance \& Management Review, 34(2), 139-165. [Google Scholar]

Cao, X., \& Ali, A. (2018). Enhancing team creative performance through social media and transactive memory system. International Journal of Information Management, 39, 69-79. [Google Scholar] [CrossRef]

Cao, X., \& Yu, L. (2019). Exploring the influence of excessive social media use at work: A three-dimension usage perspective. International Journal of Information Management, 46, 83-92. [Google Scholar] [CrossRef]

Carlson, J. R., Zivnuska, S., Carlson, D. S., Harris, R., \& Harris, K. J. (2016). Social media use in the workplace: A study of dual effects. Journal of Organizational and End User Computing, 28(1), 15-28. [Google Scholar] [CrossRef]

Catalsakal, S. (2016). How trait mindfulness is related to job performance and job satisfaction: self-regulation as a potential mediator. Ota Doğu Teknik Üniversitesi Sosyal Bilimler Enstitüsü, Yayınlanmamış Yüksek Lisans Tezi, Ankara. [Google Scholar]

Charoensukmongkol, P. (2014). Effects of support and job demands on social media use and work outcomes. Computers in Human Behavior, 36, 340-349. [Google Scholar] [CrossRef]

Charoensukmongkol, P. (2015). Social media use and job performance: Moderating roles of workplace factors. international journal of cyber behavior. Psychology and Learning (IJCBPL), 5(2), 59-74. [Google Scholar] [CrossRef]

Demircioglu, M. A. (2018). Examining the effects of social media use on job satisfaction in the Australian public service: Testing self-determination theory. Public Performance \& Management Review, 41(2), 300-327. [Google Scholar] [CrossRef]

Demircioglu, M. A., \& Chen, C. A. (2019). Public employees' use of social media: Its impact on need satisfaction and intrinsic work motivation. Government Information Quarterly, 36(1), 51-60. [CrossRef] [Google Scholar]

El Ouirdi, A., El Ouirdi, M., Segers, J., \& Henderickx, E. (2015). Employees' use of social media technologies: a methodological and thematic review. Behaviour \& Information Technology, 34(5), 454-464. [Google Scholar] [CrossRef]

Fisher, C. D. (2003). Why do lay people believe that satisfaction and performance are correlated? Possible sources of a commonsense theory. Journal of Organizational Behavior: The International Journal of Industrial, Occupational and Organizational Psychology and Behavior, 24(6), 753-777. [Google Scholar] [CrossRef]

Fornell, C., \& Larcker, D. F. (1981). Evaluating structural equations models with unobservable variables and measurement error. Journal of Marketing Research, 18(1), 39-50. [Google Scholar] [CrossRef]

Fox, J., \& Moreland, J. J. (2015). The dark side of social networking sites: An exploration of the relational and psychological stressors associated with Facebook use and affordances. Computers in human behavior, 45, 168-176. [Google Scholar] [CrossRef] Gaskin, J. (2016). Excel StatTools. Stats tools package. Retrieved from http://statwiki.kolobkreations.com/

George, D., \& Mallery, M. (2003). Using SPSS for Windows step by step: a simple guide and reference.. Boston: Allyn \& Bacon. Gonzalez, E., Leidner, D., Riemenschneider, C., \& Koch, H. (2013). The impact of internal social media usage on organizational socialization and commitment. In Proceedings of the 34th International Conference on Information Systems (ICIS), Milan (1-18) [Google Scholar]

Grimmelikhuijsen, S. G., \& Meijer, A. J. (2015). Does Twitter increase perceived police Legitimacy?. Public Administration Review, 75(4), 598-607. [Google Scholar] [CrossRef]

Haddud, A., Dugger, J. C., \& Gill, P. (2016). Exploring the impact of internal social media usage on employee engagement. Journal of Social Media for Organizations, 3(1), 1-23. [Google Scholar]

Hair, J. F., Hult, G. T. M., Ringle, C., \& Sarstedt, M. (2014). A Primer on Partial Least Squares Structural Equation Modeling. Sage. [Google Scholar]

Hair, J. F., Black, W. C., Babin, B. J., Anderson, R. E., Tatham, R. L. (2006). Multivariate data analysis (6th Ed.). PearsonPrentice Hall, Upper Saddle River, NJ.

Hanna, B., Kee, K. F., \& Robertson, B. W. (2017). Positive impacts of social media at work: Job satisfaction, job calling, and Facebook use among co-workers. In SHS web of conferences, 33, 00012. [Google Scholar] [CrossRef]

Hayes, A. F. (2017). Introduction to mediation, moderation, and conditional process analysis: A regression-based approach. New York, NY: Guilford. [Google Scholar]

Holland, P., Cooper, B. K., \& Hecker, R. (2016). Use of social media at work: a new form of employee voice?. The International Journal of Human Resource Management, 27(21), 2621-2634. [Google Scholar] [CrossRef]

Jafar, R. M. S., Geng, S., Ahmad, W., Niu, B., \& Chan, F. T. (2019). Social media usage and employee's job performance. Industrial Management \& Data Systems, 119(9), 1908-1925. [Google Scholar] [CrossRef]

Kaplan, A. M., \& Haenlein, M. (2010). Users of the world, unite! The challenges and opportunities of Social Media. Business Horizons, 53(1), 59-68. [Google Scholar] [CrossRef]

Lam, H. K., Yeung, A. C., \& Cheng, T. E. (2016). The impact of firms' social media initiatives on operational efficiency and innovativeness. Journal of Operations Management, 47, 28-43. [Google Scholar] [CrossRef]

Leftheriotis, l., \& Giannakos, M. N. (2014). Using social media for work: Losing your time or improving your work? Computers in Human Behavior, 31, 134-142. [Google Scholar] [CrossRef]

Leidner, D., Koch, H., \& Gonzalez, E. (2010). Assimilating generation Y IT new hires into USAA's workforce: The role of an enterprise 2.0 system. MIS Quarterly Executive, 9(4), 229-242. [Google Scholar] 
Leonardi, P. M., Huysman, M., \& Steinfield, C. (2013). Enterprise social media: Definition, history, and prospects for the study of social technologies in organizations. Journal of Computer-Mediated Communication, 19(1), 1-19. [Google Scholar] [CrossRef]

Locke, E. A. (1976). The nature and causes of job satisfaction. Handbook of Industrial and Organizational Psychology. [Google $\underline{\text { Scholarl }}$

Mantymaki, M., \& Riemer, K. (2016). Enterprise social networking: A knowledge management perspective. International Journal of Information Management, 36(6), 1042-1052. [Google Scholar] [CrossRef]

Marsh, H., Morin, A. J. S., Parker, P. D., \& Kaur, G. (2014). Exploratory structural equation modeling: An integration of the best features of exploratory and confirmatory factor analysis. Annual Review of Clinical Psychology, 10, 85-110. [Google Scholar] [CrossRef]

Mogbel, M. (2012). The effect of the use of social networking sites in the workplace on job performance. PhD. Dessertation, Texas A\&M International University[Google Scholar]

Mogbel, M., \& Aftab, F. (2015). Employees' social networking site use impact on job performance: evidence from Pakistan. Transactions on Replication Research, 1, 1-11. [Google Scholar] [CrossRef]

Moqbel, M., \& Kock, N. (2018). Unveiling the dark side of social networking sites: Personal and work-related consequences of social networking site addiction. Information \& Management, 55(1), 109-119. [Google Scholar] [CrossRef]

Moqbel, M., Nevo, S., \& Kock, N. (2013). Organizational members' use of social networking sites and job performance: An exploratory study. Information Technology \& People, 26(3), 240-264. [Google Scholar] [CrossRef

Munene, A. G., \& Nyaribo, Y. M. (2013). Effect of social media pertication in the workplace on employee productivity. International Journal of Advances in Management and Economics, 2(2), 141-150. [Google Scholar]

Peng, Y. P. (2014). Job satisfaction and job performance of university librarians: A disaggregated examination. Library \& Information Science Research, 36(1), 74-82. [Google Scholarl [CrossRef]

Pitafi, A. H., Kanwal, S., Ali, A., Khan, A. N., \& Ameen, M. W. (2018). Moderating roles of IT competency and work cooperation on employee work performance in an ESM environment. Technology in Society, 55, 199-208. [Google Scholar] [CrossRef]

Preacher, K. J., \& Hayes, A. F. (2004). SPSS and SAS procedures for estimating indirect effects in simple mediation models. Behavior research methods, instruments, \& computers, 36(4), 717-731. [Google Scholar] [CrossRef]

Roberts, J. A., \& David, M. E. (2020). Boss phubbing, trust, job satisfaction and employee performance. Personality and Individual Differences, 155, 109702. [Google Scholar] [CrossRef]

Robertson, B. W., \& Kee, K. F. (2017). Social media at work: The roles of job satisfaction, employment status, and Facebook use with co-workers. Computers in Human Behavior, 70, 191-196. [Google Scholar] [CrossRef]

Bin, A. S. (2015). The relationship between job satisfaction, job performance and employee engagement: An explorative study. Issues in Business Management and Economics, 4(1), 1-8. [Google Scholar] [CrossRef]

Shujaat, A., Rashid, A. \& Muzaffar, A. (2019). Exploring the Effects of Social Media Use on Employee Performance: Role of Commitment and Satisfaction. International Journal of Human Capital and Information Technology Professionals (IJHCITP), 10(3), 1-19. [Google Scholar] [CrossRef]

Song, Q., Wang, Y., Chen, Y., Benitez, J., \& Hu, J. (2019). Impact of the usage of social media in the workplace on team and employee performance. Information \& Management, 56(8), 103160. [Google Scholar] [CrossRef]

Turban, E., Bolloju, N., \& Liang, T. P. (2011). Enterprise social networking opportunities, adoption, and risk mitigation. Journal of Organizational Computing and Electronic Commerce, 21, 202-220. [Google Scholar] [CrossRef]

Walker, J. T., \& Maddan, S. (2013). Statistics in criminology and criminal justice (4 ed.): Jones \& Bartlett Learning. [Google $\underline{\text { Scholarl }}$

Yu, L., Cao, X., Liu, Z., \& Wang, J. (2018). Excessive social media use at work: exploring the effects of social media overload on job performance. Information Technology \& People, 31(6), 1091-1112. [Google Scholar] [CrossRef]

Zhang, \& Venkatesh, V. (2013). Explaining employee job performance: The role of online and offline workplace communication networks. MIS Quarterly, 37(3), 695-722. [Google Scholar] [CrossRef]

Zhang, X., Ma, L., Xu, B., \& Xu, F. (2019). How social media usage affects employees' job satisfaction and turnover intention An empirical study in China. Information \& Management, 56(6), 103-136. [Google Scholar] [CrossRef]

Маан Алхатееб,

Ph.D., Технічний університет в Палестині, Палестина

Раніа Абдалла,

Технічний університет в Палестині, Палестина

Інновації в управлінні людськими ресурсами: вплив використання соціальних мережам працівниками на їх продуктивність праці

Розвиток соціальних мереж обумовив зміни у всіх аспектах ведення бізнес діяльності, зокрема, в управлінні людськими ресурсами. У статті зазначено, що компанії все частіше застосовують соціальні мережі як інструментарій для спрощення обміну інформацією між працівниками, удосконалюючи інноваційний процес та підвищуючи рівень продуктивності праці співробітників. Застосування нових інформаційних технологій, таких як соціальні мережі, 
M. Alkhateeb, R. Abdalla. Innovations in Human Resource Management: Impact of Social Media Use on Employees' Performance

дозволяють компаніям ефективно використовувати наявні можливості та мотивувати працівників використовувати соціальні мережі з метою рутинизації бізнес-знань та розвитку інноваційних компетенції. Метою статті $є$ визначення впливу соціальних мереж на рівень продуктивності праці співробітників. В основі даної роботи лежить оцінювання ефректів від користування соціальними мережами співробітниками в особисних та професійних цілях у робочий час. Детерміновану вибірку даних сформовано на основі результатів закритого анкетування співробітників трьох компаній регіону Тулкарм. Аналіз панельних даних здійснено з використанням програмного забезпечення SPSS ma IBM SPSS Amos 24. Результати дослідження свідчать, що вплив користування соціальними мережами у просесійних иілях на рівень продуктивності праці співробітників зажелить від рівня їх задоволеності роботою. При цьому використання соціальних мереж в особистих цілях не впливає на ефективність виконання трудових обов'язків. Отримані результати дослідження мають теоретичне та практичне значення. Зокрема, дослідження соиіальних мереж з точки зору професійного та особистого використання підвищує иінність наявного наукового доробку, особливо, в контексті Палестини. У свою чергу, результати дослідження можуть бути використані менеджерами компаній з метою мотивації співробітників використовувати соціальні мережі у професійних цілях, а використання соціальних мереж в особистих цілях повинно підлягати моніторингу та контролю.

Ключові слова: комунікації, задоволення роботою, продуктивність, соціальні мережі для особистих цілей.

Manuscript received: 29.09.2019

(C) The author(s) 2020. This article is published with open access at Sumy State University. 